\title{
Growth and yield parameters of white oat and wheat as affected by canola residue
}

\author{
Samuel Luiz Fioreze $e^{1 *}$ (D), Jonathan Vacari ${ }^{1}$, Thais Lemos Turek ${ }^{2}$, Luiz Henrique Michelon ${ }^{1}$, Robson Pelissari Drun ${ }^{1}$
}

\author{
$10.1590 / 0034-737 X 201966060002$
}

\begin{abstract}
Despite being an important crop option for Brazilian agriculture, canola has some characteristics that may limit its insertion in some cropping systems, such as its allelopathic effects. Thus, the present work aimed to study the effect of canola crop residues on the seed germination, growth and grain yield of white oat and wheat plants. In laboratory conditions, white oat (Milton) and wheat (Tbio Pioneiro) seeds were germinated in the presence of aqueous extracts of (i) aboveground part, (ii) root system, (iii) whole plant and (iv) twice the concentration of the whole plant extract, besides a control. In green house conditions, the same oat and wheat cultivars were grown until harvest, on soil mixed with fresh canola crop residues (whole plant residues, aboveground residues and root residues) and a control. Aqueous extract of the whole canola plant reduced the germination and increased abnormal seedlings of white oat and wheat, mainly in high concentration. For soil crop, the presence of canola residues did not affect the white oat emergence, growth and grain yield. For wheat, plant emergence was lower in the presence of canola residues, but growth and yield were not affected.
\end{abstract}

Keywords: Brassica napus, Avena sativa; Triticum aestivum; allelopathy; off-season cropping.

\section{INTRODUCTION}

The great adaptation of the canola (Brassica napus) in Brazilian tropical regions, such as Goiás and Minas Gerais states (Estevez et al., 2014), shows a potential for cropping in warmer seasons in the southern of the country. This way of crop, known as off-season, is little explored in Santa Catarina and Rio Grande do Sul states. In these areas, a long period without cropping is observed between the summer crop harvesting and winter crop sowing (April to June). In this way, an additional crop can be inserted in these production systems, improving incomes in addition to secondary benefits, such as nutrient cycling, soil cover and weed management.

Despites its potential for cropping in Brazil, canola plants show traits that may be limiting in field conditions, such as allelopathic effects in next crops. Glucosinolates are allelochemical compounds found in Brassica species, which negatively affect seed germination and plant growth (Bones \& Rossiter, 1996). In general, both wild and cultivated Brassica species have some kind of allelopathic effect (Rehman et al., 2013) with potential to reduce weed infestation (Siemens et al., 2002). Some Brassica species, however, have chemical compounds, as Brassinolide, which promotes the growth of some crops (Grove et al., 1979). Isolated Brassinolide of these plants, for example, could increase the maize plants tolerance to drought stress (Anjum et al., 2011).

The suppressive effect of canola plant residues has been demonstrated for summer crops, as soybean (Haddadchi \& Gerivani, 2011; Silva et al., 2011), sunflower (Jafariehyazdi \& Javidfar, 2011; Yasumoto et al., 2011), common bean (Rigon et al., 2012) and weeds as Bidens

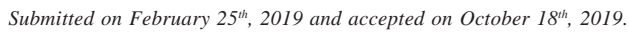

${ }^{1}$ Universidade Federal de Santa Catarina, Departamento de Ciências Biológicas e Agronômicas, Curitibanos, Santa Catarina, Brazil. s.fioreze@ufsc.br; vacari.j@gmail.com; luizhenriquemichelon@gmail.com; robsondrun20@gmail.com

${ }^{2}$ Universidade do Estado de Santa Catarina, Centro de Ciências Agroveterinárias, Lages, Santa Catarina, Brazil. thaisturek@yahoo.com.br

* Corresponding author: s.fioreze@ufsc.br 
pilosa (Rizzardi et al., 2008; Moraes et al., 2012) and Lolium spp (Asaduzzaman et al., 2014a; Asaduzzaman et al., 2016). Most of these effects are demonstrated under germination and seedling growth. Grain yield in succession to the canola cropping is, however, few studied (Silva et al., 2011; Yasumoto et al., 2011).

Whereas the potential for canola off-season cropping in South of Brazil, it is necessary to identify if the allelopathic effects, observed on weeds and summer crops, will manifest on subsequent winter crops, such as wheat (Triticum aestivum) and white oat (Avena sativa), for example. This behavior is especially important for shorttime conditions between canola harvesting and subsequent crop sowing. In this way, this work aimed to study the effect of canola crop residues on seed germination, growth and grain yield of white oat and wheat plants.

\section{MATERIALAND METHODS}

Two experiments were carried out from August to December 2016, using white oat and wheat plants. Experimental area is at $1010 \mathrm{~m}$ altitude, at Curitibanos, Santa Catarina state, Brazil. The region climate is $\mathrm{Cfb}$ type (Climate-Data, 2018).

First experiment was carried out in laboratory conditions, to study the effects of aqueous extracts of canola plants on wheat (TBIO Pioneiro) and white oat (Milton) seed germination. The extracts were obtained following the methodology described by Rizzardi et al. (2008), with some adaptations (freeze drying was replaced by a forced circulation oven method). At the physiological maturation stage, the plants were collected and taken to the laboratory for asepsis and then cut into pieces approximately five centimeters long. The dried material (65 ${ }^{\circ} \mathrm{C}$ ) was milled in a Willey-mill type. The extract was obtained after 24 hours of milled residues immersion in Mili-Q water, on stirring at mild temperature.

The experimental design was a completely randomized with four replications. The treatments were performed by a control (pure water) and four aqueous extract: (i) aboveground part, (ii) roots (iii) whole plant with, $8 \mathrm{~g} 100$ $\mathrm{mL}^{-1}$ and (iv) $16 \mathrm{~g} 100 \mathrm{~mL}^{-1}$. Replications of 50 seeds were distributed on plastic box (gerbox) with two paper towel leaves moistened with $8 \mathrm{~mL}$ of the aqueous extract and kept in germinator at $25^{\circ} \mathrm{C}$ and photoperiod of 12 hours. Every 12 hours, the plastic boxes were randomized inside the germinator. Germinated seeds, normal and abnormal seedlings and no germinated seeds were determined at eight day after seeding, based on the criteria established in the Rules for Seed Testing (Brasil, 2009).

Second experiment was carried out in greenhouse conditions, to study the effects of canola plants residues on wheat (TBIO Pioneiro) and white oat (Milton) growth and yield. The experimental was a randomized complete block design with four replications. The treatments were performed by a control (no residue) and three kinds of fresh plant residues: (i) aboveground part, (ii) roots (iii) whole plant. Each experimental unit consisted of a $11 \mathrm{dm}^{3}$ polyethylene pot filled with a limed soil.

The soil is a Cambissolo Háplico típico (Brazilian classification; Santos et al., 2013) or an inceptisol, with a

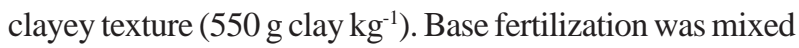
with the soil and consisted of $135 \mathrm{mg} \mathrm{dm}^{-3}$ of potassium chloride $\left(60 \%\right.$ of $\left.\mathrm{K}_{2} \mathrm{O}\right), 1.8 \mathrm{~g} \mathrm{dm}^{-3}$ of triple superphosphate (44\% of $\mathrm{P}_{2} \mathrm{O}_{5}$ ). Side dressing nitrogen fertilization took place 2, 23 and 44 days after seedling emergence (DAE) and consisted of urea (45\% of N) applied via solution (50 mg $\mathrm{dm}^{-3}$ of $\mathrm{N}$ ). The greenhouse has been programmed to maintain a temperature of $20^{\circ} \mathrm{C}$ during the day and $15^{\circ} \mathrm{C}$ at night. The relative humidity of the air was kept between 50 and $65 \%$. Irrigation was performed manually, taking care to avoid water percolation in the pot.

Canola plant residues were obtained from a field commercial cropped. At the physiological maturation stage, the plants were collected and separated, according treatments. The amount of 10 ton $\mathrm{ha}^{-1}$ was used, considering the plot area. Proportion of aboveground part (86.4\%) and root $(13.6 \%)$ portion was determined to establish the treatments. Thus, the amount of vegetal residue for the treatment with only aboveground part was of 8.64 ton ha${ }^{1}$, whereas the treatment with root system residues received an amount equivalent to 1.36 ton $\mathrm{ha}^{-1}$.

In each pot, eight seeds were sown at $3-\mathrm{cm}$ depth. Seedling emergence was determined daily until process stabilization, when thinning was performed, maintaining three plants per pot. At flowering stage, plant height and number of tillers were determined in all plants in each pot. At the same period, one plant from each pot was collected to dry mass determination (leaves, culms and reproductive structures). At maturation stage, plant dry mass, yield and yield components were determined. For all experiments, data was submitted to variance analysis by the F test ( $p<$ $0.05)$. Means were compared by the Tukey test $(p<0.05)$.

\section{RESULTS AND DISCUSSION}

Extracts of canola plants did affect the seed germination of wheat and white oat (Table 1). For wheat seeds, lower amount of normal seedlings at eight days after sowing was obtained when aboveground extract was used, mainly for double of concentration. For these extracts, higher values for abnormal seedlings were obtained. Similar results were observed by Tawaha \& Turk (2003) in wild barley seeds germinated on Brassica nigra extracts. In white oat seeds, double-concentration extract resulted in higher values for abnormal seedlings. Aboveground and root 
extract did not differ from control values for germination parameters.

For soil sowing conditions, canola residues affected the germination of wheat seeds (Figure 1a), so the highest amount of seedlings emerged at five days after sowing (DAS) was observed for the control, without residues. The main difference for seedlings emergence occurred between the control and the addition of residues of canola roots. Aboveground residue, isolated or combined with root residue, showed intermediate values for emerged seedlings. The emergence of oat seedlings, on the other hand, was not affected by the presence of canola crop residues (Figure $1 b)$.

The number of germinated seeds, in laboratory conditions, was not affected by canola residues. Rigon et al. (2012) observed that aqueous extract of canola leaves reduced the speed seed germination and increased the occurrence of abnormal seedlings, by inhibition of secondary roots, although did not affect the percent of germinated seeds. Al-Sherif et al. (2013), however, observed that under higher concentrations of aqueous extracts of $B$. nigra, wheat seed germination may be completely inhibited due to inactivation of the hydrolytic enzymes proceeding seed germination.

Glucosinolates concentration in Brassica tissues is well related in literature (Haramoto \& Gallandt, 2004; Norsworthy et al., 2005; Bangarwa et al., 2011). Enzymatic hydrolysis of these compounds liberates various compounds (mainly isothiocyanates) that could inhibit seed germination (Haramoto \& Gallandt, 2004). Ferulic and syringic acids (phenolic compounds) were the dominant allelochemicals found in B. nigra using HPLC (high performance liquid chromatography) method by AlSherif et al., 2013, who suggest that the combined toxic action of such allelochemicals and isothiocyanates is more effective on seed germination and seedling growing. According to Einhellig et al. (2004) partial or complete germination inhibition may be attributed to several factors, as inactivation of the hydrolytic enzymes, death of embryos in seeds (lethal concentrations), reduction cell expansion due to water stress and, suppression for cell division.

It is interesting to note that the highest values of abnormal seedlings (wheat and white oat) were observed

Table 1: Normal and abnormal seedling and not germinated seeds (NG) of wheat (TBIO Pioneiro) and white oat (Milton) at eight days after seeding in aqueous extracts of canola plants

\begin{tabular}{|c|c|c|c|c|c|c|}
\hline \multirow{2}{*}{$\begin{array}{l}\text { Aqueous } \\
\text { extract }\end{array}$} & \multicolumn{3}{|c|}{ Wheat } & \multicolumn{3}{|c|}{ White oat } \\
\hline & Normal & Abnormal & NG & Normal & Abnormal & NG \\
\hline Control & $70.0 \mathrm{a}$ & $18.5 \mathrm{~b}$ & 11.5 & $44.5 \mathrm{a}$ & $52.5 \mathrm{ab}$ & 3.0 \\
\hline Aboveground (A) & $41.5 \mathrm{bc}$ & $35.5 \mathrm{ab}$ & 23.0 & $19.5 a b$ & $75.5 \mathrm{ab}$ & 5.0 \\
\hline Root (R) & $61.5 \mathrm{ab}$ & $19.0 \mathrm{~b}$ & 19.5 & $67.0 \mathrm{a}$ & $29.5 \mathrm{~b}$ & 3.5 \\
\hline$A+R$ & $56.0 \mathrm{ab}$ & $27.0 \mathrm{~b}$ & 17.0 & $28.0 \mathrm{ab}$ & $67.0 \mathrm{ab}$ & 5.0 \\
\hline$A+R[2 x]^{1}$ & $23.5 \mathrm{c}$ & $55.0 \mathrm{a}$ & 21.5 & $10.0 \mathrm{~b}$ & $79.5 \mathrm{a}$ & 10.5 \\
\hline$p$ & 0.00 & 0.00 & 0.06 & 0.02 & 0.04 & 0.15 \\
\hline $\mathrm{CV}(\%)$ & 23.08 & 28.26 & 13.11 & 64.86 & 34.76 & 77.32 \\
\hline
\end{tabular}

Means followed by the same letter in the column do not differ by the Tukey test $(\mathrm{p}<0.05)$; ${ }^{1}$ double of concentration; CV: Coefficient of variation.
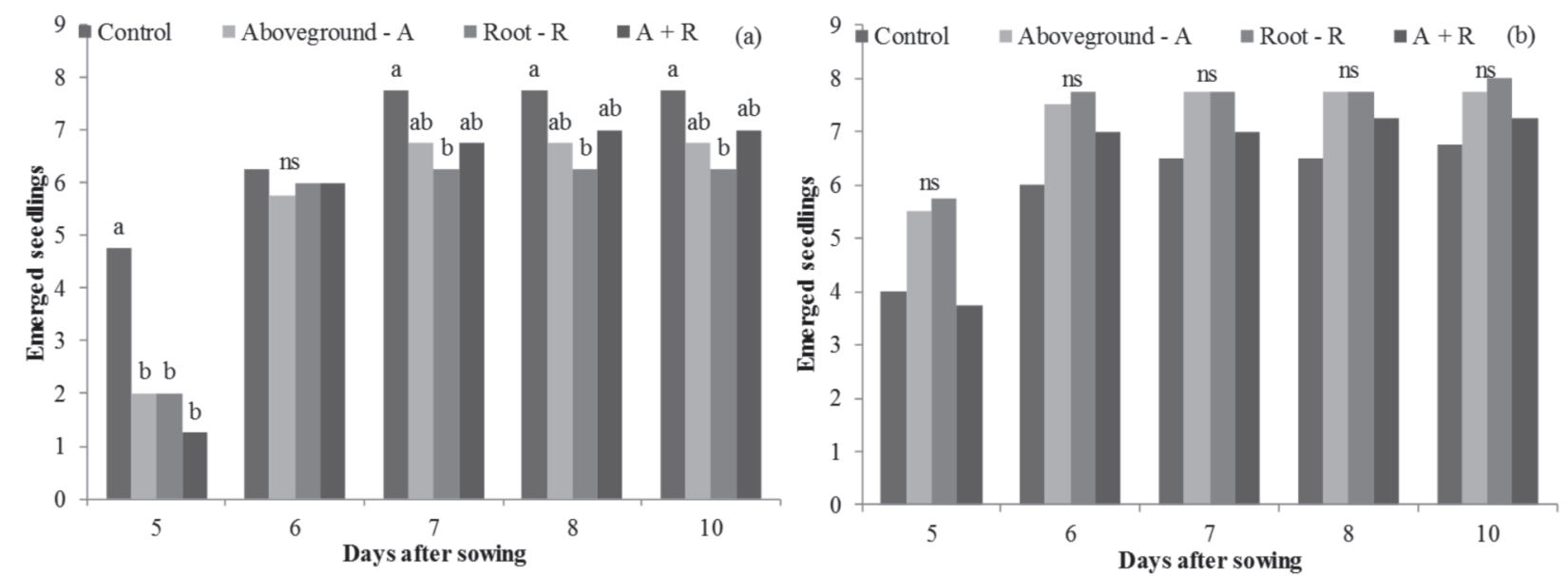

Figure 1: Wheat (a) and white oat (b) emerged seedlings as a function of canola plant residues on soil. Means followed by the same letter in the column do not differ by the Tukey test $(\mathrm{p}<0.05)$.

Rev. Ceres, Viçosa, v. 66, n.6, p. 416-421, nov/dec, 2019 
for aboveground extract of canola plants (Table 1), while the lowest values of seedlings emerged in soil were observed for root system residues. Effects of root canola residues were observed by Yasumoto et al. (2011) in sunflower plants. These authors identified the presence of some volatile substances and other soluble in water, in roots. These substances are able to self-inhibit canola seed germination. According the authors, these substances are released from plants during development stage or even during initial decomposition, after harvesting. Jafariehyazdi \& Javidfar (2011) demonstrated reducing on sunflower seed germination and root and hypocolyl length, in aqueous extract of canola and other Brassica species, as B. rapa e B. juncea. These effects were more pronounced in higher concentrations of the extracts, manly those obtained from full flowering plants. A dose-dependent inhibition of B. nigra extract was related by Al-Sherif et al. (2013) in wheat seeds.

Higher glucosinolates concentration was found in aboveground parts of a mixture of Brassica juncea and Sinapsis alba (Norsworthy et al., 2005). This result could explain the higher effect of aboveground extract under seed germination in laboratory conditions, where seeds were in direct contact with the extract. In this case, a joint effect of the compounds glucosinolates and phenolic compounds is expected. Whereas the glucosinolates and the products of its hydrolysis show relatively high vapor pressure Haramoto \& Gallandt, 2004), the higher effect of root residues under seed germination in greenhouse conditions could be more related to phenolic compounds. In this case, higher concentration of phenolic compounds should be expected in root tissue. Other explanation could be related to a dilution effect on pot cultivation.

The effects of canola residues have also been demonstrated in ryegrass species. Asaduzzaman et al. (2014a) observed reduction on root growth of Lolium rigidum plants when intercropped with canola plants in high density, using the ECAM method (Equal Compartment Agar Method). Similar results were obtained by Asaduzzaman et al. (2014b). According Asaduzzaman et al. (2016) Lolium rigidum can (i) stop growing, (ii) change its growing direction or (iii) die, when they find allelochemical compounds of canola plants.

Canola plant residues also inhibit the germination and growth of soybean seedlings, with a more pronounced effect of the root extract (Haddadchi \& Gerivani, 2011), although Nunes et al. (2014) did not observe this effect. For Bidens pilosa, however, the inhibition of seed germination is more intense in aboveground extracts, which can fully inhibit germination (Rizzardi et al., 2008; Moraes et al., 2012). Naeem et al. (2017) showed negative effects

Table 2: Morphologic and yield parameters of wheat plants (TBIO Pioneiro) as a function of canola plant residues on soil

\begin{tabular}{|c|c|c|c|c|c|}
\hline Residue & Height $(\mathrm{cm})$ & LDM (g) & $\mathrm{CDM}(\mathrm{g})$ & SDM (g) & NT \\
\hline Control & 97.00 & 3.68 & 6.08 & 1.73 & 8.92 \\
\hline Aboveground (A) & 102.25 & 3.44 & 7.59 & 2.21 & 8.84 \\
\hline Root (R) & 94.50 & 2.90 & 5.92 & 1.66 & 8.08 \\
\hline$A+R$ & 94.38 & 3.00 & 5.97 & 1.74 & 8.50 \\
\hline$p$ & 0.23 & 0.32 & 0.18 & 0.35 & 0.44 \\
\hline$\overline{\mathrm{CV}(\%)}$ & 5.78 & 19.43 & 17.59 & 24.76 & 8.88 \\
\hline Residue & PDW (g) & $\mathrm{SDM}^{1}(\mathrm{~g})$ & NS & $\mathrm{RL}(\mathrm{cm})$ & SPS \\
\hline Control & 9.16 & 1.76 & 8.13 & 7.65 & 14.51 \\
\hline Aboveground (A) & 9.13 & 1.94 & 7.50 & 8.06 & 14.96 \\
\hline Root (R) & 8.63 & 2.04 & 9.13 & 7.58 & 14.12 \\
\hline$A+R$ & 8.60 & 2.05 & 8.63 & 7.61 & 13.76 \\
\hline$p$ & 0.76 & 0.61 & 0.3 & 0.68 & 0.31 \\
\hline $\mathrm{CV}(\%)$ & 11.15 & 17.01 & 13.92 & 8.13 & 6.16 \\
\hline Residue & GS & GMS (g) & NFT & NIT & TNT \\
\hline Control & 34.10 & 1.25 & 8.13 & 0.63 & 8.75 \\
\hline Aboveground (A) & 36.28 & 1.34 & 7.50 & 0.88 & 8.38 \\
\hline Root (R) & 29.96 & 1.12 & 9.13 & 0.00 & 9.13 \\
\hline$A+R$ & 31.67 & 1.21 & 8.63 & 0.75 & 9.38 \\
\hline$p$ & 0.31 & 0.53 & 0.29 & 0.26 & 0.47 \\
\hline$\overline{\mathrm{CV}(\%)}$ & 14.31 & 17.52 & 13.92 & 109.87 & 10.26 \\
\hline
\end{tabular}

LDM: leaf dry matter; CDM: culm dry matter; SDM: spike dry matter; NT: number of tillers; PDW: plant dry matter; SDM ${ }^{1}$ : spike dry matter at maturation; NS: number of spikes; RL: rachis length; SPS: number of spikelets per spike; GS: number of grains per spike; GMS: grain mass per spike; NFT: number of fertile tillers; NIT: number of infertile tillers; TNT: total number of tillers; CV: Coefficient of variation. 
of canola residues on corn seed germination and plant growth. In soil conditions, however, corn plant growing was not affected by canola residues, although Raphanus sativus and Crambe abyssinica (same family) residues have reduced plant root growth (Spiassi et al., 2011). Despite of the potential of allelopathic effects of canola residues observed in laboratory essays, some results indicates that this effect can be mitigated, or even suppressed through interaction with soil components, especially water, considering the soluble nature of the substances present in canola plants.

The presence of canola residues did not affect the biomass accumulation and yield parameters of the wheat (Table 2). Even with the delay in the seedling emergence (Figure 1a), both tillering and yield parameters were not affected. For white oat, the biomass accumulation and yield parameters were not affected (Table 3), according to germination (Table 1) and emergence (Figure 1b) parameters.

Although the effects of canola residues are well described on seed germination and seedling emergence, few studies have demonstrated these effects on crop yield. Yasumoto et al. (2011) observed reduction on plant growth and yield of sunflower cropped after canola harvesting. Silva et al. (2011) demonstrated an allelopathic effect of canola on soybean yield, manly in reduced rainfall period, indicating the important role of rainfall in promoting the loading or even degradation of the soluble compounds present in these residues. Similar results were observed by Nozaki \& Tomazelli (2014), who indicated a period from 10 to 20 days between canola harvest and soybean sowing, to minimize allelopathic effects.

The results obtained in this study are promising, from the technological view. Even though there is an allelopathic effect of canola residues on some annual summer crops, or even on annual winter and weed plants, white oat and wheat plants development was not affected. Thus, in off-season cropping of canola for climatic conditions in the South and Southeast regions of Brazil, the insertion of the crop into the production system would not affect subsequent crops, as wheat or oats. In addition, it should be considered that in field conditions the degradation or even the leaching of allelopathic compounds is potentiated by the occurrence of rains or even thermal oscillation. Finally, the mitigation phenomenon, or even the suppression of the allelopathic effects of canola residues, helps to explain the differences between the laboratory results and those obtained in soil, either in the field or greenhouse conditions.

Table 3: Morphologic and yield parameters of white oat plants (Milton) as a function of canola plant residues on soil

\begin{tabular}{|c|c|c|c|c|c|}
\hline Residue & Height (cm) & $\operatorname{LDM}(\mathrm{g})$ & CDM (g) & PDM (g) & NT \\
\hline Control & 140.75 & 4.04 & 8.77 & 1.89 & 5.34 \\
\hline Aboveground (A) & 143.13 & 4.18 & 9.60 & 2.25 & 4.67 \\
\hline Root (R) & 145.88 & 4.61 & 10.35 & 2.57 & 5.50 \\
\hline$A+R$ & 142.88 & 4.30 & 9.06 & 1.89 & 5.58 \\
\hline$p$ & 0.96 & 0.67 & 0.54 & 0.4 & 0.58 \\
\hline $\mathrm{CV}(\%)$ & 9.25 & 15.45 & 16.86 & 28.95 & 19.03 \\
\hline Residue & PDW (g) & $\mathrm{PDM}^{1}(\mathrm{~g})$ & NP & PL (cm) & SPP \\
\hline Control & 15.84 & 1.31 & 6.88 & 19.57 & 34.76 \\
\hline Aboveground (A) & 17.05 & 1.34 & 6.75 & 19.35 & 34.54 \\
\hline Root (R) & 15.62 & 1.13 & 6.50 & 19.95 & 33.92 \\
\hline$A+R$ & 18.57 & 1.34 & 7.75 & 19.73 & 31.85 \\
\hline$p$ & 0.48 & 0.67 & 0.75 & 0.98 & 0.93 \\
\hline $\mathrm{CV}(\%)$ & 16.98 & 22.11 & 24.57 & 10.02 & 20.25 \\
\hline Residue & GP & $\operatorname{GMP}(\mathrm{g})$ & NFT & NIT & TNT \\
\hline Control & 68.63 & 1.91 & 6.88 & 1.13 & 8.0 \\
\hline Aboveground (A) & 65.52 & 1.99 & 6.75 & 1.25 & 8.0 \\
\hline Root (R) & 67.50 & 1.98 & 6.5 & 0.25 & 6.7 \\
\hline$A+R$ & 62.38 & 1.98 & 7.75 & 0.25 & 8.0 \\
\hline$p$ & 0.97 & 0.1 & 0.75 & 0.15 & 0.72 \\
\hline $\mathrm{CV}(\%)$ & 28.47 & 37.15 & 24.57 & 101.24 & 24.21 \\
\hline
\end{tabular}

LDM: leaf dry matter; CDM: culm dry matter; PDM: panicle dry matter; NT: number of tillers; PDW: plant dry matter; PDM ${ }^{1}$ : panicle dry matter at maturation; NP: number of panicle; PL: panicle length; SPP: number of spikelets per panicle; GP: number of grains per panicle; GMP: grain mass per panicle; NFT: number of fertile tillers; NIT: number of infertile tillers; TNT: total number of tillers; CV: Coefficient of variation.

Rev. Ceres, Viçosa, v. 66, n.6, p. 416-421, nov/dec, 2019 


\section{CONCLUSIONS}

At high concentration, aqueous extracts of Canola plants (shoots and roots) have a negative effect on the germination of wheat and oat seeds, in the laboratory;

Canola plants residues did not affect seedling emergence, growth and yield of white oat plants;

Canola plants residues have negative effect on wheat seedling emergence, but did not affect plant growth and yield;

\section{CONFLICT OF INTEREST}

First author is, currently, journal session editor.

\section{REFERENCES}

Al-Sherif E, Hegazy AK, Gomaa NH \& Hassan MO (2013) Allelopathic effect of black mustard tissues and root exudates on some crops and weeds. Planta Daninha, 31:11-19.

Anjum SA, Wang LC, Farooq M, Hussain M, Xue LL \& Zou CM (2011) Brassinolide application improves the drought tolerance in maize through modulation of enzymatic antioxidants and leaf gas exchange. Journal of Agronomy and Crop Science, 195:420-426.

Asaduzzaman M, An M, Pratley JE, Luckett DJ \& Lemerle D (2014a) Laboratory bioassay for canola (Brassica napus) allelopathy. Journal of Crop Science and Biotechnology, 17:267272

Asaduzzaman M, An M, Pratley JE, Luckett DJ \& Lemerle D (2014b) Canola (Brassica napus) germplasm show variable allelopathic effects against annual ryegrass (Lolium rigidum). Plant Soil, 380:47-56.

Asaduzzaman M, An M, Pratley JE, Luckett DJ, Lemerle D \& Coombes N (2016) The seedling root response of annual ryegrass (Lolium rigidum) to neighbouring seedlings of a highlyallelopathic canola (Brassica napus). Flora, 219:18-24.

Bangarwa SK, Norsworthy JK, Mattice JD \& Gbur EE (2011) Glucosinolate and isothiocyanate production from brassicaceae cover crops in a plasticulture production system. Weed Science, $59: 247-254$

Bones AM \& Rossiter JR (1996) The myrosinase glucosinolate system: An innate defense system in plant. Physiologia Plantarum, 97:194-208.

Brasil (2009) Ministério da Agricultura, Pecuária e Abastecimento. Regras para análise de sementes. Brasília, Mapa/ACS. 395p.

Climate-Data (2018) Dados Climáticos para cidades mundiais. Available at: <http://pt.climate-data.org/>. Accessed on: November $30^{\text {th }}, 2018$.

Einhellig FA, Galindo JCG, Molinillo JMG \& Cutler HG (2004) Mode of allelochemical action of phenolic compounds. In: Macías FA, Galindo JCG, Molinillo JMG \& Cutler HG (Eds.) Allelopathy: chemistry and mode of action of allelochemicals. London, CRC Press. p.217-238.

Estevez RL, Duarte JB, Chambo APS \& Cruz MIF (2014) A cultura da canola (Brassica napus var. oleifera). Scientia Agraria Paranaensis, 13:01-09.

Grove D, Gayland F \& William K (1979) Brassinolide, a plant growth-promoting steroid isolated from Brassica napus pollen. Nature, 281:216-217.
Haddadchi GR \& Gerivani Z (2009) Effects of phenolic extracts of canola (Brassica napus L.) on germination and physiological responses of soybean (Glycine $\max$ L.) seedlings. International Journal of Plant Production, 03:63-73.

Haramoto ER \& Gallandt ER (2004) Brassica cover cropping for weed management: A review. Renewable Agriculture Food System, 19:187-198.

Jafariehyazdi E \& Javidfar F (2011) Comparison of allelopathic effects of some Brassica species in two growth stages on germination and growth of sunflower. Plant Soil Environment, 57:52-56.

Moraes PVD, Agostinetto D, Panozzo LE, Galon L, Oliveira C \& Dal Magro T (2012) Potencial alelopático de extratos aquosos de culturas de cobertura de solo na germinação e desenvolvimento inicial de Bidens pilosa. Semina, 33:1299-1314.

Naeem M, Nisar U, Khalid F, Mehmood A \& Ali HH (2017) Quantifying allelopathic effect of rapeseed on germination and seedling growth of maize under different salinity levels. Zemdirbyste Agriculture, 104:259-266.

Norsworthy JK, Brandenberger L, Burgos NR \& Riley M (2005) Weed suppression in Vigna unguiculata with a spring-seeded brassicaceae green manure. Crop Protection, 24:441-447.

Nozaki MH \& Tomazelli IC (2014) Produtividade da soja em épocas de semeadura com e sem resíduos vegetais de canola. Agrarian, 07:511-520.

Nunes JVD, Melo D, Nóbrega LHP, Loures NTP \& Sosa DEF (2014) Atividade alelopática de extratos de plantas de cobertura sobre soja, pepino e alface. Caatinga, 27:122-130.

Rehman MWU, Hussain M, Ali M, Mustafa CB, Shafi J \& Iqbal F (2013) Allelopathy of Brassica. A review. Scientia Agriculturae, 08:222-229.

Rigon JPG, Capuani S, Cherubin MR, Watowski AD \& Rosa GM (2012) Allelopathic effects of aqueous extract of Brassica napus on germination of seed of Phaseolus vulgaris. Revista Brasileira de Ciências Agrárias, 07:451-455.

Rizzardi MA, Neves R, Lamb TD \& Johann LB (2008) Potencial alelopático da cultura da canola (Brassica napus L. Var. Oleifera) na supressão de picão-preto (Bidens sp.) e soja. Revista Brasileira de Agrociência, 14:239-248.

Santos HG, Jacomine PKT, Anjos LHC, Oliveira VA, Lumbreras JF, Coelho MR, Almeida JA, Cunha TJF \& Oliveira JB (2013) Sistema brasileiro de classificação de solos. $3^{\mathrm{a}}$ ed. Brasília, Embrapa. 353p.

Siemens DH, Garner SH, Mitchell-Olds T \& Callaway RM (2002) Cost of defense in the context of plant competition: Brassica rapa may grow and defend. Ecology, 83:505-517.

Silva JAG, Motta MB, Bianchi CAM, Crestani M, Gaviraghi J, Fontaniva C \& Gewber E (2011) Alelopatia da canola sobre o desenvolvimento e produtividade da soja. Revista Brasileira de Agrociência, 17:428-437.

Spiassi A, Fortes AMT, Pereira DC, Senem J \& Tomazoni D (2011) Alelopatia de palhadas de coberturas de inverno sobre o crescimento inicial de milho. Semina, 32:577-582.

Tawaha AM \& Turk MA (2003) Allelopathic effects of black mustard (Brassica nigra) on germination and growth of wild barley (Hordeum spontaneum). Journal of Agriculture and Crop Science Research, 189:298-303.

Yasumoto S, Suzuki K, Matsuzaki M, Hiradate S, Oose K, Hirokane H \& Okada K (2011) Effects of plant residue, root exudate and juvenile plants of rapeseed (Brassica napus L.) on the germination, growth, yield and quality of subsequent crops in successive and rotational cropping systems. Plant Production Science, 14:339-348. 